\title{
NOTAS INTRODUTÓRIAS SOBRE A TEORIA E AS CATEGORIAS CENTRAIS PARA A PESQUISA DA PROBLEMÁTICA DO LAZER
}

Elza Margarida de Mendonça Peixoto

\section{RESUMO:}

Este artigo trata da indicação da teoria e das categorias que o Grupo de Estudos e Pesquisas Marxismo, História, Tempo Livre e Educação tem considerado centrais para a apreensão e explicação do lazer enquanto realidade que se efetiva no processo de desenvolvimento das forças produtivas e das relações de produção em diferentes formações sociais, e, em especial, na formação social brasileira.

Palavras-Chave: trabalho, tempo livre, modo de produção capitalista, categorias, teoria.

\section{INTRODUCTORY NOTES ON THE THEORY AND THE CENTRAL CATEGORIES FOR THE INQUIRY OF THE PROBLEMATICS OF THE LEISURE}

\section{ABSTRACT:}

This article deals with of theory and categories indication wich, the "Studies and Research Group of Marxism, Story, Freetime and Education", has been considered central to the Leisure understanding and explanation as a reality that effective it in the development process of productive forces and relations of production in many different social formations and in the Brazilian social formation especially.

Keyword: work, free time, way of capitalist production, categories, theory.

\section{Introdução}

\footnotetext{
"A questão de saber se cabe ao pensamento humano uma verdade objetiva não é uma questão teórica, mas prática. É na práxis que o homem deve demonstrar a verdade, isto é, a realidade e o poder, o caráter terreno de seu pensamento. A disputa sobre a realidade ou não-realidade do pensamento isolado da práxis - é uma questão puramente escolástica (MARX, Karl. Teses Sobre Feuerbach. 1845).
}

Os estudos do lazer brasileiros - sem realizar grandes incursões históricas resolveram o problema da origem do lazer de duas formas: (1) realizando levantamentos dos sentidos de ócio e scholé nas sociedades greco-romanas; (2) remetendo a origem do lazer ao momento histórico da transição da sociedade tradicional para a sociedade moderna. Nos dois casos, recorrendo-se à etimologia (meras expressões no pensamento de um movimento real jamais enfrentado pelos estudiosos) ou às transformações no modo de produção da existência (reduzido às transformações nos meios de produção descoladas das relações mais amplas de produção que expressam a luta de classes em cada momento histórico), são produzidas explicações que se apresentam historicamente limitadas, teoricamente frágeis e inconsistentes. Tal situação decorre, essencialmente, do abandono 
do recurso às teorias de longo alcance, consideradas incapazes de explicar uma realidade "multifacetada" que estaria caracterizando uma suposta pós-modernidade.

Frente a estes limites evidentes na explicação histórica da problemática do lazer na contramão do abandono das microteorias - argumentamos, neste artigo, em defesa (1) da possibilidade, à luz da história ciência, do conhecimento científico sobre o que é e como se produz o lazer (enquanto prática, política e produção do conhecimento); (2) de que esta possibilidade se concretiza na Concepção Materialista e Dialética da História, enquanto o referencial teórico consolidado e lastreado em categorias consistentes e rigorosas capturadas na realidade objetiva - que viabilizam explicar o desenvolvimento histórico desta problemática a partir das bases materiais nas quais este desenvolvimento se efetiva; (3) de que a explicação da problemática do lazer só se torna possível a partir do conhecimento radical e rigoroso dos nexos históricos nos quais este se efetiva como prática inscrita nas leis de desenvolvimento contraditório e dialético dos diferentes modos de produção da existência em diferentes momentos históricos; (4) de que as formas mais avançadas de um dado fenômeno guardam referências (marcas) fundamentais para se compreender o menos avançado (FREITAS, 1995, p. 78), ou seja, que a apreensão das formas modernas do lazer - enquanto prática, política e produção do conhecimento que se desenvolve no próprio movimento de nascimento e desenvolvimento do modo capitalista de produção - permitirá o entendimento das formas menos avançadas de sua fruição em diferentes modos de produção da existência ao longo da história da humanidade; (5) que esta possibilidade de conhecimento científico não se faz lastreada em abstrações desmaterializadas a priori, mas em intensa investigação que permitem reconhecer, em última instância, que o que é o homem só pode ser reconhecido, quando reconhecemos o modo como ele se produz (SAVIANI, 2007); por fim, (6) que o lazer deve ser explicado no seio de cada modo de produção em estudo, à luz da análise das condições históricas que o produzem; (7) que na perspectiva da concepção materialista e dialética da história, os estudos do lazer devem buscar reconhecer o estágio de desenvolvimento das forças produtivas e das relações de produção que o engendram como prática, política e produção do conhecimento.

Enfrentando e tomando posição ante a questão filosófica sobre a viabilidade de o pensamento humano captar a verdade objetiva (em movimento) sobre o lazer - defendendo esta viabilidade - este artigo trata da indicação da teoria e das categorias que o Grupo de Estudos e Pesquisas Marxismo, História, Tempo Livre e Educação tem considerado centrais para a apreensão e explicação do lazer enquanto realidade que se efetiva no processo de desenvolvimento das forças produtivas e das relações de produção próprias ao modo capitalista de produção da existência, dedicando atenção especial à forma particular como este se desenvolve na formação social brasileira. Tal posicionamento decorre da constatação dos dados da realidade que nos permitem afirmar que as leis gerais do desenvolvimento histórico do capitalismo, embora mais complexas, permanecem as mesmas e são hegemônicas em todo o mundo, determinando o conteúdo e a forma como os homens comem, bebem, se vestem, habitam, se locomovem, investigam, apreendem e explicam o real, estando na totalidade destas relações a forma como se divertem.

Ao reconhecer que as leis gerais que orientam as relações de produção próprias do capitalismo não mudaram e determinam a vida dos homens, reconhecemos e reafirmamos que o eixo teórico - que explicita e orienta a crítica da economia política tal como ela ocorre no capitalismo e que permite o desenvolvimento das teses elaboradas por Marx e Engels - permanece atual e adequado para a análise deste modo de produção, e de todas as práticas que nele são engendradas. Ou seja, ante as teorias científicas desenvolvidas ao longo da história dos homens com a finalidade de conhecer a realidade (no todo ou em suas 
partes) - o positivismo, a fenomenologia e o marxismo - reafirmamos a cientificidade, a profundidade, a abrangência e a superação proporcionadas pela Concepção Materialista e Dialética da História (marxismo), enquanto teoria do conhecimento que viabiliza o salto qualitativo e quantitativo no olhar para o fragmento - ou suas conexões e relações mais imediatas - em busca das relações históricas mais amplas que determinam o real, teoria que defende "uma concepção unitária de ciência", a história "como uma ciência de síntese" (FERNANDES, 1989, p. 10).

Este teoria vai sendo produzido por Karl Marx e Friedrich Engels no final da primeira metade do século XIX, em um movimento intenso de apropriação crítica de tudo o que naquele tempo era mais avançado: a dialética idealista hegeliana, a especulação filosófica que visou superá-la, a economia política, o socialismo utópico e a história burguesa que já havia descrito e entendido as classes sociais ${ }^{1}$. Este movimento fica registrado em uma profusão de escritos que nascem do combate cotidiano (LENIN, 1979; FERNANDES, 1989, p. 12) e que visavam responder às questões que surgiam das lutas de classes travadas no período de consolidação do capitalismo como modo de produção da existência predominante. Escritos que tomaram o partido do movimento operário em luta pela superação da exploração sob as relações capitalistas de produção a que viviam subordinados (ENGELS, 1985) que Marx e Engels dedicaram-se a compreender e explicar, ao qual, no método da escrita, na síntese, deram o nome de capital, em um período ao qual Erick Hobsbawm acaba por nomear A era do capital (1996).

Este eixo teórico aparece delineado a partir de A Ideologia Alemã (MARX, K.; ENGELS, F., 1845-1846), e perfeitamente estruturado e explicado no Prefácio à Contribuição à crítica da economia política (MARX, K.,1859), sendo posteriormente anunciado nos prefácios e em várias passagens das obras $O$ capital: crítica da economia política (MARX, K., 1867) ou Origens da família, da propriedade privada e do Estado (ENGELS, F., 1884). Os elementos centrais deste eixo teórico são: (1) a prática como critério de verdade: os indivíduos reais, a sua ação e as suas condições materiais de existência; (2) o princípio da anterioridade da existência material em relação à consciência: a existência como pré-requisito para qualquer ação, intenção ou pensamento humano; (3) a existência como dependente da ação direta de produzi-la (alimentar-se, habitar, agasalharse, produzir o alimento, o agasalho, a habitação - satisfazer as necessidades essenciais para existir); (4) a produção da existência enquanto realidade dependente da (a) condição física dos homens (do estágio da complexidade corporal), (b) das condições naturais, geológicas, orográficas, hidrográficas, climáticas que se lhe deparam já elaboradas, (c) do estágio de desenvolvimento das forças com as quais os homens vão realizar a produção, produto do seu próprio desenvolvimento anterior; (5) o modo de produção da existência - entendido como as complexas, contraditórias e dialéticas relações estabelecidas entre o estágio de desenvolvimento das forças produtivas e as disputas pela posse destas forças - como determinante, em última instância, das relações que os homens estabelecem ente si e com a natureza; (6) as idéias, as representações, a consciência, a religião, a história produzidas por estes indivíduos, como práticas diretamente dependentes do modo como produzem os seus meios de vida; por fim, (7) a defesa da viabilidade de o homem conhecer e revolucionar o mundo real que lhe é exterior, com o qual se relaciona, a partir do qual produz sua existência, ao qual transforma, e em cuja ação transformadora ressurge transformado; (8) e a defesa da viabilidade do conhecimento da realidade que determina toda a existência humana estar determinada pelo conhecimento das bases naturais e de sua modificação provocada pelos homens no decurso da história (MARX, K.; ENGELS, F.; 1974, p. 18-19). 
Estas teses foram defendidas por Marx e Engels no conjunto da obra posterior a 1845, evidenciando-se, em síntese, nas palavras de Engels, apresentando a teoria que orienta sua incursão sobre a Origem da família, da propriedade privada e do Estado: [...] De acordo com a concepção materialista, o fator decisivo na história é, em última instância, a produção e a reprodução da vida imediata (ENGELS, 1995, p. 2); e de forma precisa, em Marx, ao explicar o eixo teórico que sustenta e orienta seus estudos:

Nas minhas pesquisas cheguei à conclusão de que as relações jurídicas assim como as formas de Estado - não podem ser compreendidas por si mesmas, nem pela dita evolução geral do espírito humano, inserindo-se pelo contrário nas condições materiais de existência de que Hegel, à semelhança dos ingleses e franceses do século XVIII, compreende o conjunto pela designação de sociedade civil; por seu lado, a anatomia da sociedade civil deve ser procurada na economia política. [...] A conclusão geral a que cheguei e que, uma vez adquirida, serviu de fio condutor dos meus estudos, pode formular-se resumidamente assim: na produção social da sua existência, os homens estabelecem relações determinadas, necessárias, independentes da sua vontade, relações de produção que correspondem a um determinado grau de desenvolvimento das forças produtivas materiais. $\mathrm{O}$ conjunto destas relações de produção constitui a estrutura econômica da sociedade, a base concreta sobre a qual se eleva uma superestrutura jurídica e política e a qual correspondem determinadas formas de consciência social. $\mathrm{O}$ modo de produção da vida material condiciona o desenvolvimento da vida social, política e intelectual em geral. Não é a consciência dos homens que determina o seu ser; é o seu ser social que, inversamente, determina a sua consciência. Em certo estágio de desenvolvimento, as forças produtivas materiais da sociedade entram em contradição com as relações de produção existentes ou, o que é a sua expressão jurídica, com as relações de propriedade no seio das quais se tinham movido até então. De formas de desenvolvimento das forças produtivas, estas relações transformam-se no seu entrave. Surge então uma época de revolução social. A transformação da base econômica altera, mais ou menos rapidamente, toda a imensa superestrutura. Ao considerar tais alterações é necessário sempre distinguir entre a alteração material - que se pode comprovar de maneira cientificamente rigorosa - das condições econômicas de produção, e as formas jurídicas, políticas, religiosas, artísticas ou filosóficas, em resumo, as formas ideológicas pelas quais os homens tomam consciência deste conflito, levando-o às suas últimas conseqüências. Assim como não se julga um indivíduo pela idéia que ele faz de si próprio, não se poderá julgar uma tal época de transformação pela mesma consciência de si; $e ́$ preciso, pelo contrário, explicar esta consciência pelas contradições da vida material, pelo conflito que existe entre as forças produtivas sociais $\boldsymbol{e}$ as relações de produção. Uma organização social nunca desaparece antes que se desenvolvam todas as forças produtivas que ela é capaz de conter; nunca relações de produção novas e superiores se lhe substituem antes que as condições materiais de existência destas relações se produzam no próprio seio da velha sociedade. É por isso que a humanidade só levanta os problemas que é capaz de resolver e assim, numa observação atenta, descobrir-se-á que o problema só surgiu quando as condições materiais para o resolver já existiam ou estavam, pelo menos, em vias de aparecer (MARX, 1977, p. 24-25). 
Sob estas premissas propostas por Marx e Engels, buscamos apreender, no próprio desenvolvimento das forças produtivas e das relações de produção capitalistas, o movimento material, real, contraditório e dialético dos conflitos de interesses no vínculo com suas bases materiais que levam à produção das práticas, das políticas e das idéias referentes ao lazer na formação social brasileira, inscrita no movimento mais amplo do capital monopólico e do imperialismo (XIX aos dias atuais). Trata-se, em última instância, (1) de afirmar que é possível produzir um conhecimento verdadeiro sobre o lazer - ainda que provisório, em face de uma realidade em constante movimento; (2) de perquirir sobre o que é o lazer e como ele se produz na formação social brasileira - ou seja, na própria história do desenvolvimento das forças produtivas e das relações de produção concretas que se desenvolveram no Brasil (XIX aos dias atuais); (3) de explicar os nexos e contradições nos quais se desenvolvem as práticas, as políticas e a produção do conhecimento referentes aos lazer no Brasil, denunciado os interesses em disputa subjacentes à sua promoção na formação social brasileira.

Mas explicar o que é o lazer e como ele se produz pede que ultrapassemos (1) a pesquisa empírica que se limita a catalogar o real, extraindo o objeto da realidade e descrevendo-o isolado dos nexos históricos em que é produzido; e (2) a pesquisa fenomênica, que relativiza as possibilidades de conhecimento do real, sustentando-se nas especulações e abstrações teóricas e subjetivistas. O conhecimento sobre o que é o lazer pede que reconheçamos como ele se produz em uma dada formação social. Trata-se de explicar os nexos nos quais as práticas, as políticas e a produção do conhecimento referentes ao lazer estão inscritas no modo de produção capitalista e em suas correspondentes relações de produção. Partimos (1) dos pressupostos da Concepção Materialista e Dialética da História (marxismo) tal como elaborados por Marx e Engels e acima assinalados; e (2) do confronto entre (a) a produção do conhecimento hegemônica sobre a problemática do lazer, vigente no Brasil; e (b) a realidade, o meio material concreto, a partir do qual são produzidas as práticas, as políticas e o conhecimento referentes à problemática do lazer na formação social brasileira.

\title{
Apontamentos acerca do que é o lazer e como ele se produz
}

\author{
...através da divisão do trabalho, torna-se possível [...] que a \\ atividade intelectual e material - o gozo e o trabalho, a produção e \\ o consumo, caibam a indivíduos distintos (MARX e ENGELS, \\ 1974, p. 37-38).
}

A pergunta sobre o que é o lazer não pode continuar a ser respondida na forma reduzida e recorrente à alusão ao tempo em que ocorre, à atividade que se pratica ou ao modo como os indivíduos se sentem ou agem neste tempo e nesta atividade - à subjetividade. Não pode ser resolvida com o recurso à crítica abstrata às categorias que têm estruturado as explicações vigentes, como no obscuro debate sobre o caráter do tempo (é um tempo livre, é um tempo disponível?). Nem tão pouco pode ser solucionada em formulações conceituais retóricas, escolásticas e a-históricas. A pergunta sobre o que é o lazer só pode ser respondida quando acompanhada da questão prática que trata do modo como ele se produz em um contexto histórico determinado. Assim, a possibilidade de saber o que é o lazer depende da investigação dos processos históricos que permitem e determinam a sua produção, que devem ser reconhecidos entre a forma particular do seu acontecimento em uma dada formação social no movimento das relações complexas e contraditórias que este contexto particular estabelece com o modo como se processa a 
produção universal em um dado momento histórico.

Em primeiro lugar, temos claro que o lazer é uma prática dos homens. Como tal, depende (1) da existência de homens vivos para que se efetive; e (2) da atividade vital continuada destes homens pela qual produzem e reproduzem sua existência. Esta atividade vital, esta produção da existência é, na sua forma mais elementar e particular, o próprio trabalho, a condição fundamental de toda a vida humana (ENGELS, 1979, p. 215), [...] indispensável à existência do homem - quaisquer que sejam as formas de sociedade necessidade natural e eterna de efetivar o intercâmbio material entre o homem e a natureza, e, portanto, de manter a vida humana (MARX, 1989, p. 50). Esta atividade vital de produção da existência - este trabalho - realiza-se determinado pelo estágio de desenvolvimento das forças produtivas e das relações de produção, reconhecidas, em sua forma geral, como o modo de produção (comunal, escravocrata, feudal ou capitalista). O lazer (tomando-se as práticas desenvolvidas em um tempo determinado e em relações determinadas) é, em primeiro lugar, um produto histórico do trabalho humano, tomado em sua forma concreta e abstrata. Configurando-se como um produto do trabalho, explica-se imbricado na totalidade contraditória e dialética na qual o trabalho (atividade vital à manutenção da existência humana) se efetiva em diferentes modos de produção da existência (ou seja, conjunto histórico composto pelo universo do estágio de desenvolvimento das forças produtivas e das relações de produção em determinados contextos - comunal, escravista, feudal, capitalista - nos quais a humanidade - o ser social - se produz) ${ }^{2}$.

Noutras palavras, a pergunta sobre o que é e como se produz o lazer está profundamente imbricada na explicação sobre o que é e como se produz o trabalho de produção da existência individual e social em diferentes modos de produção, posto que a possibilidade de fruição do lazer, depende, em última instância, da produção de condições objetivas para que se efetive o usufruto do tempo, das atividades e dos valores - tomados em cada momento histórico, de acordo com as concepções de diferentes grupos sociais inseridos em formações sociais diferenciadas determinadas pelo estágio de desenvolvimento das forças produtivas e das relações de produção.

Ontologicamente, portanto, o lazer é um produto da atividade vital do homem enquanto ser social, e objetiva-se nas mesmas condições nas quais objetiva-se o trabalho. Ora, na concepção de história que abraçamos, não se trata de inventar uma "nova" explicação para um objeto isolado do real, mas de explicar o objeto no seio das relações históricas que o produzem. $\mathrm{O}$ que fazemos a seguir, marcados pelo limite objetivo da necessidade de pesquisas mais minuciosas que permitam conhecer a estrutura e a superestrutura de cada modo de produção em cada momento histórico. Trata-se, portanto, de um esboço preliminar de uma teoria explicativa para a problemática do lazer que só se concretizará na e pela pesquisa lastreada na ciência história.

\section{Modo de produção escravista, ócio e scholé}

Sob esta orientação, o ócio e a scholé serão explicados como práticas de homens liberados da produção, no contexto das relações de produção que estão postas em uma sociedade cujo estágio de desenvolvimento das forças produtivas pede uma divisão social do trabalho baseada no trabalho escravo para a produção agrícola. Estas condições de produção da existência determinam o lazer como uma prática privilegiada dos homens livres da necessidade de trabalhar para produzir a existência.

$O$ modo de produção feudal, o licere.

No modo de produção feudal, o licere será explicado no conjunto de relações 
feudais marcadas pela dependência econômica e política entre clero, nobreza, vassalos e servos. Sem qualquer romantismo sobre a relação entre homem e natureza na "sociedade tradicional", a dura e árdua vida do servo da gleba reduz-se à produção para o sustento dos nobres e do clero que habitam o feudo, e o direito de interromper as atividades de produção da existência está subordinado e determinado (1) pela necessidade de produção dos bens necessários à manutenção da existência social a partir de forças produtivas elementares ${ }^{3}$, tais como a terra dividida em pequenos lotes, cultivada por pequenos grupos de famílias a partir do uso de ferramentas rudimentares: a pá, a enxada, ou o arado, (2) em relações de produção nas quais, na divisão social do trabalho, repousam sobre a nobreza a segurança coletiva, sobre o clero o zelo pela manutenção da proteção divina e o controle das servos, assumindo estas classes, em relações de conflito, as decisões sobre o direito de acesso às forças produtivas (à terra, às ferramentas, às técnicas), o direito de ir e vir, o direito à vida. o produtor imediato - o camponês - estava unido ao meio de produção - o solo - por uma relação social de servidão. Ligados à terra: os servos juridicamente tinham mobilidade restrita (ANDERSON, 1987, p. 143).

Os camponeses que ocupavam e cultivavam a terra não eram seus proprietários. A propriedade agrícola era controlada privadamente por uma classe de senhores feudais, que extraíam um excedente de produção dos camponeses através de uma relação político legal de coerção. Esta coerção extra-econômica, tomando a forma de serviços, arrendamentos em espécie ou obrigações consuetudinárias ao senhor individual pelo camponês, era exercida tanto na própria terra senhorial diretamente ligada à pessoa do senhor, como nas faixas pequenas de arrendamento (ou virgates) cultivadas pelo camponês. Seu efeito foi necessariamente um amálgama de exploração econômica e autoridade política. O camponês estava sujeito à jurisdição de seu senhor. Ao mesmo tempo, os direitos de propriedade do senhor sobre sua terra geralmente eram apenas de grau: o senhor era investido neles por um nobre (ou nobres) superior, a quem passaria a dever serviços de cavaleiro - o fornecimento de um efetivo militar em tempos de guerra. Em outras palavras, suas propriedades eram mantidas como um feudo. O senhor feudal, por seu lado, muitas vezes seria vassalo de um senhor feudal superior, e a cadeia de tais posses dependentes se estenderia até o cume do sistema - na maioria dos casos, um monarca - de quem, a princípio, toda a terra, em última instância, seria o eminente domínio. Típicas ligações intermediárias de tal hierarquia feudal no início dessa época, entre o simples senhorio e o monarca soberano, eram a castelania, o baronato, o condado ou o principado. A conseqüência deste sistema era que a soberania política nunca estava enfocada em um único centro. As funções do Estado desagregavam-se em concessões verticais sucessivas, e a cada nível estavam integradas as relações econômicas e políticas. Esta parcelarização da soberania seria constitutiva de todo o modo de produção feudal (ANDERSON, 1987, p. 144).

A classe camponesa que produzia o excedente estava subordinada a um mundo social de direitos e poderes superpostos (ANDERSON, 1987, p. 145).

[...] a parcelização da soberania no início da Europa medieval também levou à constituição de uma ordem ideológica isolada. A Igreja, que no final da Antiguidade estivera sempre integrada à máquina do Estado imperial, e a ela subordinada, agora se tornava uma instituição 
eminentemente autônoma dentro da forma de governo feudal. Única fonte de autoridade religiosa, seu domínio sobre as crenças e valores da massa era imenso; mas sua organização eclesiástica era diferente da de qualquer nobreza ou monarquia secular. Devido à dispersão da coerção inerente ao feudalismo ocidental que surgia, a Igreja podia defender seus próprios interesses particulares, se necessário, a partir de um reduto territorial, e pela força armada. Os conflitos institucionais entre o senhorio leigo e o religioso eram então endêmicos no período medieval: seu resultado foi uma cisão na estrutura da legitimidade feudal, cujas consequiências culturais para o desenvolvimento intelectual posterior seriam consideráveis (ANDERSON, 1987, p. 148).

O exercício da justiça, sob o feudalismo tornou-se a modalidade central do poder político assim especificado pela própria natureza da forma de governo feudal, que incluía um elenco mais amplo de atividades do que a justiça moderna porque estruturalmente ocupava uma posição bem mais central dentro de todo o sistema político (ANDERSON, 1987, p. 148). O feudo era o centro do poder político e econômico na Idade Média, configurando-se na alternativa mais eficiente para a ocupação e controle do campo, mas também gerará uma estrutura social de poder fracionado. $\mathrm{O}$ estágio de desenvolvimento das forças produtivas pede o uso intenso da força de trabalho do servo, os seja, das forças naturais do corpo a fim de apropriar-se da natureza, imprimindo-lhes forma útil à vida humana (MARX, 1989, p. 202). O senhor tinha a obrigação de proteger os servos da ameaça constante da rapina viking ou mulçumana (ANDERSON, 1987, p. 152). Os servos tinham a obrigação de prestar serviços (produção agrícola, criação de animais, indústria caseira - fabrico e consertos de instrumentos de trabalho, utensílios domésticos diversos, movelaria, tecelagem - etc.) e ceder parte da produção agrícola. Estas relações de obrigação eram a base do feudalismo e iniciavam-se com a cessão, por parte do senhor feudal - que detinha o direito de dispor da terra - de lotes de terras a indivíduos que por relações pessoais de subordinação convertiam-se em vassalos e servos. Embora seja dono dos instrumentos de trabalho e controle o processo de trabalho como um todo, o estágio de desenvolvimento das forças produtivas, lastreado na manufatura e no artesanato, impõe à família de servos grande quantidade de tarefas que exaurem e consomem o dia. Ocupados com a produção da existência que sustenta toda a ordem feudal, os servos tinham a vida subsumida ao trabalho de produzi-la, e as formas de descanso e divertimento estão subordinadas e determinadas por estas relações de produção. Também os senhores, obrigados a defender os feudos, dedicavam boa parte do seu tempo à arte da guerra, ao exercício da justiça e à política.

Sob estas condições, o direito social ao gozo de um tempo livre para uma atividade livre, enquanto construção jurídica, para os servos da gleba, inexiste, estando subordinado aos ciclos da natureza, à hierarquia da complexa organização social feudal e ao clero. $\mathrm{O}$ mesmo movimento de análise deve ser feito para as corporações de ofício que vão se formando, juntamente com as cidades feudais, na passagem do artesanato para a manufatura, que, progressivamente, vai dando lugar à indústria, e vai produzindo as duas classes centrais que tronar-se-ão as bases das relações próprias ao modo capitalista de produção.

Com estas notas, apontamos que o conhecimento do modo como se produzia e fruía algum tipo de tempo livre no período feudal, deve - ultrapassando estudos etimológicos abstraídos do movimento real que produz os vocábulos - considerar a estrutura econômica que deu base à superestrutura política, jurídica e religiosa que regulou as relações de trabalho e o gozo do tempo livre do trabalho, este último, determinado fundamentalmente 
pela divisão social do trabalho que amarrou alguns à produção da existência e deu a outros tempo liberado para produzir e usufruir das artes e do conhecimento disponível.

\section{O modo de produção capitalista, o lazer.}

O modo capitalista de produção caracteriza-se pela "imensa produção de mercadorias" (MARX, 1989, p. 41) em relações de produção marcadas (1) pelo contínuo aprimoramento das forças produtivas; e pela (2) liberdade jurídica de apropriar e dispor privadamente das forças produtivas geradas socialmente ao longo da história da humanidade. Esta "liberdade jurídica" confere (1) ao trabalhador o direito de comercializar a única propriedade que lhe resta após a revolução que deu hegemonia à burguesia: sua força de trabalho, e (2) à burguesia, o direito de comercializar os bens que acumulou no processo de seu desenvolvimento enquanto classe: a terra, as ferramentas (as máquinas) e os produtos do trabalho (as mercadorias). Como é impossível a produção de qualquer bem (valor de uso) sem a aplicação de força de trabalho sobre a natureza, o capitalismo caracteriza-se pela contraditória e dialética relação entre os proprietários dos meios de produção: o capitalista (que detém o controle de toda a natureza e das ferramentas dela extraídas ao longo da história da humanidade) e o trabalhador (que, inseparável de sua força de trabalho, a detém, e nela as técnicas e as habilidades de manuseio das ferramentas e matérias primas). Podemos dizer que as relações de produção capitalistas vão ser marcadas, pelo movimento contínuo, contraditório dialético da burguesia em direção de apropriar-se do máximo de força de trabalho com o menor custo - visto que é nesta relação que se produz a mais valia - o que inclui incorporar o máximo da técnica necessária à produção dos bens socialmente produzidos expropriando o trabalhador de suas habilidades e conhecimentos, incorporando-os às máquinas e impedindo aos trabalhadores de retomálos como conhecimentos úteis e de síntese; do proletariado em direção de defender o único bem que lhe resta: a força de trabalho na qualidade e quantidade necessárias à manutenção de sua existência no interior das próprias relações capitalistas das quais não pode desprender-se individualmente, mas apenas social e historicamente.

No eixo desta relação estrutural que orbita em torno das disputas pelas forças produtivas, encontra-se a disputa pelo direito de usufruto da riqueza socialmente produzida: o tempo livre decorrente do desenvolvimento das forças produtivas, e nele, o direito de usufruir do conhecimento que a humanidade produziu. Nestas relações, a burguesia reserva para si o que há de mais avançado na história da humanidade, repassando aos trabalhadores o essencial para que esta se mantenha produzindo de acordo com o grau e controle das forças produtivas (incluindo o próprio desenvolvimento da força de trabalho) que burguesia e classe trabalhadora vão desenvolvendo. Apenas nesta ordem é possível compreender o processo de expansão do tempo livre, e o seu usufruto na forma da apropriação e usufruto da cultura (a educação e o lazer). Quanto mais desenvolvidas as forças produtivas, menor é o tempo socialmente necessário à produção. Mas, tal como já o disse Newton Cunha, a quantidade de tempo livre a que a classe trabalhadora terá acesso depende, efetivamente, do grau de organização e poder de que disponha, ou seja, da correlação de forças que consiga construir para enfrentar e arrancar da burguesia os bens que produziu ao colocar em ação a sua força de trabalho.

No modo capitalista de produção, o lazer é, portanto produto do trabalho humano concreto (forma especializada e útil do trabalho) e abstrato (a massa pura e simples do trabalho humano em geral) configura-se, simultaneamente, (1) como tempo de repouso para o retorno eficiente da força de trabalho à produção; (2) tempo para a circulação de mercadorias e (3) uma mercadoria consumida no tempo livre do trabalho. É, ao mesmo tempo, um valor de uso, valor de troca e um valor, e, como tal, uma mercadoria - [...] um 
objeto externo, uma coisa que, por suas propriedades, satisfaz necessidades humanas, seja qual for a natureza, a origem delas, provenham do estômago ou da fantasia (MARX, 1989, p. 41).

Os estudos do lazer produzidos no Brasil ao longo do século XX e XXI buscaram, em uma primeira fase, (1) moralizar e racionalizar o tempo livre do trabalho, oferecendo acervos de atividades considerados adequados para a sua fruição; (2) aprimorar os conceitos, as categorias e as teorias explicativas para o lazer, importando as reflexões de autores estrangeiros; (3) levantar dados empíricos sobre o tempo, as atividades e as atitudes apresentadas pelos sujeitos - os trabalhadores - no processo de fruição do tempo livre; (4) aprimorar os serviços e as mercadorias a serem veiculadas no tempo livre do trabalho; (5) aprimorar a crítica ao modo como o lazer ocorre no capitalismo. Este conjunto de problemáticas apresentados pelos estudos do lazer expressam os conflitos que determinaram, na história do Brasil, o interesse pelo controle do tempo livre da classe trabalhadora. É preciso explicar esta preocupação com o controle do que a classe trabalhadora pode e não pode fazer no tempo livre à luz da análise dos conflitos de interesses entre as classes e fragmentos de classes no processo de desenvolvimento da formação social brasileira - desenvolvimento das forças produtivas e relações de produção - sem perder de vista o nexo mais amplo desta formação social com o movimento mundial do capital monopólico, ao qual, aliás, estão profundamente vinculados os interesses da burguesia brasileira.

\section{O tempo, a atividade e a subjetividade - o lazer:}

São as diferenças na divisão social do trabalho e na distribuição dos bens socialmente produzidos em cada um destes períodos que vão explicar o modo como os escravos, os servos da gleba e os trabalhadores livres - cada um no contexto histórico em que são produzidos e produzem - realizam o trabalho de produção da existência e dele se liberam. Por esta razão, produz teorias idealistas o estudioso que busca apreender o lazer a partir da etimologia a-histórica, sem o adequado entendimento das contradições e conflitos presentes em um dado estágio de desenvolvimento das forças produtivas e das relações de produção (modo de produção) em que uma dada palavra foi cunhada como expressão abstrata de um modo concreto de viver. Inscrevendo-se, portanto, em uma perspectiva idealista do conhecimento, apoiada na lógica formal, tais estudiosos não dão conta da dinâmica que produz o lazer enquanto prática, políticas e produção do conhecimento.

$\mathrm{Na}$ forma do ócio, da scholé ou do licere, referimo-nos, fundamentalmente, ao direito social ao gozo do tempo livre para uma atividade livre, que permite a produção $e$ o usufruto da arte, da literatura, da música; daquilo que convencionamos chamar de cultura, e que, em Marx e Engels, aparece como superestrutura, produto da atividade vital humana (trabalho) no processo de produção da existência. Marx e Engels esclarecem esta questão ao afirmarem que é através da divisão do trabalho que se torna possível [...] que a actividade intelectual e material - o gozo e o trabalho, a produção e o consumo, caibam a indivíduos distintos (MARX, 1974, p. 37-38). Esta explicitação está relacionada à denúncia constante de que a classe trabalhadora, no século XIX, estava impedida de acessar e usufruir deste gozo, reconhecido como o reino da liberdade passível de ser conquistado apenas quando findas as demandas decorrentes das necessidades de produção da existência. Ao explicitar esta questão, Marx e Engels constroem as condições teóricas (e políticas) para que compreendamos que, historicamente, este direito social ao gozo do tempo livre para uma atividade livre esteve sempre restrito a uma parcela da sociedade, que, detendo a posse dos meios de produção (MARX, 1989a, p. 202-203; MARX, 1989b, p. 828-882), pelo uso da força que impõe e torna hegemônicas a lógica das idéias 
dominantes, estabelece-se como classe dominante, atribuindo a escravos, servos ou trabalhadores livres a manutenção das condições necessárias à sua existência privilegiada; ou seja, aprisionando as classes que efetivamente realizam a produção, à condição de produtores da existência de toda a sociedade (a meras bestas de carga), impedidos do acesso ao direito social ao gozo do tempo livre para uma atividade livre que, na divisão social do trabalho, apenas a classe dominante vai possuir. Esta condição, entretanto, não decorre da vontade individual dos homens que existem em um determinado tempo histórico, mas do estágio de desenvolvimento das forças produtivas e das elações de produção em uma dada conjuntura:

Os homens fazem sua própria história, mas não a fazem como querem; não a fazem sob circunstâncias de sua escolha e sim sob aquelas com que se defronta diretamente, legadas e transmitidas pelo passado (MARX, 1978, p. 329).

Uma palavra para evitar possíveis equívocos. Não foi róseo o colorido que dei às figuras do capitalista e do proprietário de terras. Mas, aqui, as figuras do capitalista e do proprietário de terras só nos interessam na medida em que representam categorias econômicas, em que simbolizam relações de classe e interesses de classe. Minha concepção do desenvolvimento da formação econômico-social como um processo histórico-natural exclui, mais do que qualquer outra, a responsabilidade do indivíduo por relações, das quais ele continua sendo, socialmente, criatura, por mais que, subjetivamente, se julgue acima delas (MARX, 1989, p. 6).

A forma das relações de produção não decorre do desejo dos homens, mas são imposições da necessidade objetiva de garantir a produção da existência coletiva em determinadas condições de produção da existência decorrentes do estágio de desenvolvimento das forças produtivas e das relações de produção. Os conflitos decorrentes da escassez de recursos e da desigualdade na sua distribuição (a luta de classes) impulsiona o desenvolvimento das forças produtivas impelindo para a solução destes problemas. A produção da existência é, assim, uma sucessão contínua de produção de condições de satisfação de necessidades que complexificam-se em novas necessidades que geram nova produção. As práticas, as políticas e a produção do conhecimento são a expressão da tentativa de universalizar a satisfação de necessidades do ser em relações históricas determinadas pelo estágio de desenvolvimento das forças produtivas. É desta forma que o capitalismo, pela primeira vez na história, coloca a problemática da possibilidade de acesso ao direito social ao gozo do tempo livre para uma atividade livre para aqueles que efetivamente realizam o trabalho que permite a existência social e a produção do capitalismo como modo hegemônico de organizar a produção da existência.

Os estudos de Newton Cunha já apontaram que a definição da quantidade de tempo livre do trabalho depende: (1) do estágio de desenvolvimento das forças produtivas e das relações de produção; (2) do grau de organização e de autonomia ou poder daqueles que produzem ou mantêm a vida diária - a força de trabalho, a classe que porta a força de trabalho, a classe trabalhadora - atribuindo ênfase a este segundo aspecto (CUNHA, 1987, 9, 11-18).

O desenvolvimento das forças produtivas é resultado do intercâmbio material homem-natureza, que envolve a modificação da natureza e a modificação do próprio homem (MARX, 1989, p. 202). À medida que realiza a atividade que permite produzir a satisfação de suas necessidades (a produção de sua existência), o homem descobre as potencialidades adormecidas nos diferentes materiais imprimindo-lhes forma útil à vida 
humana. É assim que vai descobrindo meios de fazer brotar da terra o seu sustento, ora com as mãos; ora com uma pedra lascada; ora com uma pedra polida; ora com uma pá forjada do ferro bruto na brasa; ora com arados simples construídos com ferro e madeira; ora com arados complexos tracionados pelo homem e pelo animal; ora o arado movido a motor - aumentando progressivamente a capacidade real de produção de grãos e hortifrutigranjeiros. É assim que estuda a terra, a interferência do clima e do tipo de solo nos processos de germinação, a produtividade dos diferentes solos com maior ou menor quantidade de água, as possibilidades de armazenamento e controle da água de modo a dominar a quantidade que chega às plantas, de modo a superar o limite natural, passando a produzir independente das estações, as entressafras. Ao dominar os processos de produção dos bens necessários à sua sobrevivência física, os homens passam a estar aptos a ampliar a sua própria reprodução física. Ao dominar o tempo necessário a esta produção, estão aptos a dela liberar-se para a produção e atendimento de outras necessidades que permitem o desenvolvimento de sua subjetividade: a filosofia, a política, as ciências e as artes.

Evidencia-se que o homem despende um tempo de trabalho necessário à produção que é inversamente proporcional ao grau de desenvolvimento da força produtiva utilizada. Ou seja, o desenvolvimento das forças produtivas diminui o tempo necessário ao processo de arar a terra para cultivar sementes. No entanto, apesar deste tempo necessário ser menor, são as relações de produção que vão determinar o gozo - o usufruto - deste tempo livre gerado com o avanço das forças produtivas (CUNHA, 1987, p. 12). Em uma sociedade escravocrata - como a greco-romana - não é possível falar em universalização do direito social ao gozo do tempo livre para uma atividade livre, pois não existe um desenvolvimento das forças produtivas que viabilize liberar os homens (escravos) do processo de produção dos alimentos. O tempo livre para uma atividade livre (o ócio, a sckolé) era, naquele modo de produção, um privilégio dos homens liberados das tarefas de produção da vida. E esta liberação só se tornava possível pela expansão do domínio grecoromano sobre os demais povos, convertendo-os em escravos. Nestas sociedades foi o trabalho escravo que viabilizou as condições de alimentação, habitação e vestuário; foi o trabalho de guerrear que viabilizou a produção da escravatura como modelo produtivo; e foram os trabalhos de ambos que viabilizaram a existência dos homens livres para pensar e fazer filosofia e arte.

Esta formulação, originária do pensamento de Marx e Engels, e seu desdobramento no pensamento de Newton Cunha nos colocam em outro patamar ao considerar qualquer levantamento histórico acerca do direito social ao gozo do tempo livre para uma atividade livre. Em primeiro lugar, estabelecem como critérios centrais para a identificação do lazer (1) a identificação do modo como o homem produz sua existência; (2) a identificação do grau de desenvolvimento das forças produtivas que ampliam as possibilidades da produção da existência; (3) o grau de desenvolvimento das relações de produção, ou, da divisão social do trabalho; (4) a capacidade organizativa e de pressão daqueles que, na divisão social do trabalho, produzem a existência. Apoiados nestes critérios, afirmamos que é apenas no modo capitalista de produção que vão estar colocadas as condições para que, na divisão social do trabalho, a classe que realiza a produção da vida possa reivindicar o direito social ao gozo do tempo livre para uma atividade livre. Isto porque o desenvolvimento das forças produtivas, efetivamente, viabilizou as condições para o tempo socialmente necessário à produção dos bens fundamentais à manutenção da existência. Entretanto - e isto Marx e Engels também assinalaram - a apropriação privada dos meios de produção e do produto do trabalho por uma parcela diminuta da sociedade, a condição privilegiada que esta apropriação permite, impede o desenvolvimento das condições que viabilizariam o acesso da classe trabalhadora a este direito, na medida em que ameaçam 
esta condição privilegiada, uma vez que tal tempo livre pode viabilizar o reconhecimento desta situação de opressão e a consciência da necessidade de revolução de suas bases.

Podemos avançar afirmando que é no século XIX que a problemática do tempo livre para uma atividade livre, vai adquirir condições objetivas para efetivar-se, resultante, simultaneamente, do desenvolvimento das forças produtivas, das relações de produção e da organização da classe trabalhadora. Esta conjunção de acontecimentos assume força a partir da segunda metade do século XIX, tendo como um de seus momentos centrais, reconhecidos pelos estudiosos do lazer, a organização internacional da classe trabalhadora, que, viabiliza, entre outras reivindicações, o movimento pela redução da jornada de trabalho realizado pelos trabalhadores europeus na década de 80 do século XIX, cuja expressão mais conhecida no Brasil é o panfleto $O$ direito à preguiça, de Paul Lafargue (edição original, 1880, edições traduzidas para o Brasil em 1980 e em 1999).

No século XX, todos os esforços serão empreendidos para a contenção desta organização dos trabalhadores que ameaça a hegemonia da classe dos proprietários do capital. Neste processo, a luta pelo direito social ao gozo do tempo livre para uma atividade livre, vai sendo progressivamente disciplinada em um processo que envolve aquilo que Braverman vai chamar de habituação do trabalhador ao modo capitalista de produção (BRAVERMAN, 1987) ou Weinstein vai chamar, no Brasil, de (re)formação da classe trabalhadora (WEINSTEIN, 2000). Este processo de disciplinamento envolve: a corrupção de segmentos do proletariado (LENIN, 2002); a reestruturação dos processos de produção (GRAMSCI, 2001, 265-282; BRAVERMAN, 1987); o reformismo, o ataque ideológico ao comunismo conforme elaborado por Marx e Engels e a configuração da social democracia (LOMBARDI, 1993); o recuo liberal e a cessão dos direitos trabalhistas e sociais (HOBSBAWM, 1995); e a preocupação com a formação do trabalhador (WEINSTEIN, 2000; BRAGA, 2005), e com a ocupação do tempo livre (SANT'ANNA, 1994; GOMES, 2003b, MARCASSA, 2002).

Estes dados nos fazem afirmar que a problemática da ampliação do tempo livre só se coloca quando as questões objetivas para resolvê-la já estão postas. A humanidade já desenvolveu as condições objetivas para a distribuição dos bens socialmente produzidos a todos os homens indiscriminadamente, incluindo o direito social ao gozo do tempo livre para uma atividade livre. No entanto, no seio do desenvolvimento das forças produtivas, a parcela da sociedade que vem historicamente apropriando os meios de produção de modo privado - contendo o poder sob o controle das forças produtivas e buscando manter o controle das relações de produção - entrava (bloqueia) definitivamente o desenvolvimento da sociedade e dos homens. Neste contexto, o controle do tempo livre legalmente regulamentado, que viabiliza pela primeira vez na história uma possibilidade de atividade livre generalizada, deve, definitivamente, ser efetivado pela burguesia, seja pela delimitação das finalidades do tempo livre, finalidades limitadas aos interesses do desenvolvimento dos poderes da burguesia, seja pela determinação de uma diversidade de conteúdos fúteis que devem ocupar o tempo do trabalhador a fim de impedir (1) a atividade livre; (2) práticas que desgastem a força de trabalho impedindo-a de realizar-se no processo de produção emancipado. No modo capitalista de produção o direito social ao gozo do tempo livre para uma atividade livre vai sendo progressivamente, como a todas as necessidades, convertido em mercadoria luxuosa e cara (FALEIROS, 1980). O desafio não está apenas em desmascarar estas relações, mas em revolucionar a base material que as produz e explica. 


\section{Bibliografia}

ANDERSON, Perry. O modo de produção feudal. In: ANDERSON, Perry. Passagens da antiguidade ao feudalismo. São Paulo: Brasiliense, 1987.

ANDERY, Maria Amália Abib, et all. Para compreender a ciência: uma perspectiva histórica. Rio de Janeiro: Garamond, 2007.

CUNHA, Newton. A felicidade imaginada: a negação do trabalho e do lazer. São Paulo : Brasiliense, 1987.

ENGELS, Federico. A origem da família, da propriedade privada e do Estado. 13 ed. Rio de Janeiro: Bertrand Brasil, 1995.

ENGELS, Federico. A situação da classe trabalhadora na Inglaterra. São Paulo : Global, 1985.

ENGELS, Federico. Anti-Dühring. 3. ed. São Paulo: Paz e Terra, 1990. 232 p.

ENGELS, Federico. Dialética da natureza. 6. ed. Rio de Janeiro: Paz e Terra, 2000. 238 p.

ENGELS, Federico. El status quo en Alemania. In: MARX, Carlos; ENGELS, Federico.

Obras Fundamentales: Engels: escritos de juventud. México: Fondo de Cultura Económica, 1981a. p. 612-627. (Volume 2).

ENGELS, Federico. Ludwig Feuerbach e o fim da filosofia clássica alemã. In: MARX, Karl; MARX, Karl; ENGELS, Friedrich. Obras escolhidas. São Paulo: Alfa Omega, 1980.

ENGELS, Federico. Sobre Alemania. In: MARX, Carlos; ENGELS, Federico. Obras Fundamentales: Engels: escritos de juventud. México: Fondo de Cultura Económica, 1981b. p. 568-585. (Volume 2).

ENGELS, Friedrich. Esboço de uma crítica da economia política. Temas de ciências humanas, São Paulo, n. 5, p. 1-29, 1979.

FALEIROS, M. I. L. Repensando o lazer. Perspectiva, São Paulo, n. 3, p. 51-65, 1980.

LENIN, Vladimir Iilich. As três fontes $e$ as três partes constitutivas do marxismo. São Paulo: Parma, 1979.

MARCASSA, L. As faces do lazer: categoria necessárias à sua compreensão. Encontro Nacional de Recreação e Lazer, 15, Santo André. Anais... Santo André : SESCSP, Prefeitura de Santo André, 2003a (CD-ROM).

MARCASSA, Luciana. As faces do lazer: categorias necessárias à sua compreensão. Congresso Brasileiro de Ciências do Esporte, 13, Caxambú. Anais... Caxambu: CBCE, 2003b. p.

MARX, K. O 18 de Brumário de Luiz Bonaparte. In: Os pensadores. São Paulo: Abril Cultural, 1978.

MARX, K.; ENGELS, F. A ideologia alemã (Feuerbach). 9 ed. São Pulo: Hucitec, 1993.

MARX, Karl. Contribuição à crítica da economia política. São Paulo: Martins Fontes, 1977.

MARX, Karl. O Capital: crítica da economia política - o processo global da produção capitalista. Livro 3. Volume VI. Rio de Janeiro : Civilização Brasileira, s/d (b). 
MARX, Karl. O Capital: crítica da economia política - o processo de produção de capital. Livro 1. Volume I. Rio de Janeiro : Bertrand Brasil, 1989a.

MARX, Karl. O Capital: crítica da economia política - o processo de produção de capital. 12 ed. Livro 1. Volume II. Rio de Janeiro : Bertrand Brasil, 1989b.

MARX, Karl. O Capital: crítica da economia política - o processo de circulação do capital. 4 ed. Livro 2. Volume III. São Paulo: DIFEL, 1983.

MARX, Karl. O Capital: crítica da economia política - o processo global da produção capitalista. Livro 3. Volume IV. Rio de Janeiro: Civilização Brasileira, s/d (a).

MARX, Karl. O Capital: crítica da economia política - o processo global da produção capitalista. 4 ed. Livro 3. Volume V. São Paulo: DIFEL, 1985.

MARX, Karl; ENGELS, Friedrich. A ideologia alemã: crítica da filosofia alemã mais recente na pessoa dos seus representantes Feuerbach, B. Bauer e Stirner, e do socialismo alemão na dos seus diferentes profetas. Porto/ São Paulo: Editorial Presença/Livraria Martins Fontes, $1974^{4} .2$ v.

Notas:

\footnotetext{
${ }^{1}$ Florestan Fernandes, na coletânea Marx e Engels: história, questiona por que as abordagens que tratam da evolução do pensamento de Marx e Engels desprezam a influência que tiveram sobre os pais do marxismo os historiadores franceses e ingleses.

${ }^{2}$ Esta constatação faz Newton Cunha afirmar que podemos localizar em diferentes tipos de sociedade e estágios históricos, o tempo da produção e o tempo de fruição da produção. O modo como estes tempos vão estar distribuídos vai depender do estágio de desenvolvimento das forças produtivas e das relações de produção. Na mesma linha, Faleiros afirmará veementemente que o lazer não se consolida como uma categoria, porque dependente das relações com a produção das necessidades.

${ }^{3}$ Andery (2007, p. 138) alerta para a estagnação do desenvolvimento técnico e científico neste tempo que Anderson vai chamar de época triste (ANDERSON, 1987, p. 152), no qual a luta pela existência superpõe-se ao usufruto da vida.

${ }^{4}$ Não há dados sobre a data de publicação deste texto no volume que estamos utilizando. Estamos considerando aqui a informação disponibilizada pela tipografia na última página do primeiro exemplar: "Este livro acabou de se imprimir em 20 de maio de 1974 para a Editorial Presença LTDA. na Tipografia Nunes, LTDA. Rua D. João IV, 590, Porto". Uma informação disponibilizada em Bottomore (2001, p. 410) indica, por sua vez, o ano de 1980 como aquele da publicação da Primeira Edição desta obra em Português.
}

Recebido em: $\quad$ 01/02/11

Aprovado em: $17 / 03 / 11$ 